\title{
腹膜平衡機能検查における酵素法と ヤッフェ法を用いたクレアチニン測定の比較
}

\author{
中村 信也 朝 長香北條みどり 飯高 喜久雄 \\ 西田陽* \\ 北里大学小览科 同臨床病理*
}

key words：CAPD, 腹膜機能検査，クレアチニン測定，酵素法

〈要旨〉

現在クレアチニン $(\mathrm{Cr})$ の測定は, ヤッフェ直接法と酵素法で行われている。腹膜透析液には高濃度のグルコー スが含まれており，ヤッフェ直接法による Cr の測定はグルコース濃度の影響を受けるため, グルコース濃度に対 する補正が必要である。一方, 酵素法による $\mathrm{Cr}$ の測定においてはグルコース濃度の影響は受けない。今回は小児 CAPD 患者の腹膜機能検査 (PET) においてヤッフェ 直接法と酵素法により透析液中の $\mathrm{Cr}$ を測定し，両者間の差 を検討した。ヤッフェ直接法 (グルコース補正後) における D2/P (Cr) と D4/P (Cr) の平均は各々 0.494 と 0.788 で，酵素法における平均は各々 0.478 と 0.722 になり，腹膜機能の值に差がみられた $(\mathrm{p}<0.01)$ 。

$\mathrm{PET}$ における透析液中の $\mathrm{Cr}$ 值の測定は，グルコース濃度による影響が少なく，グルコース濃度の補正をせずに， $\mathrm{Cr}$ 值の測定が可能な酵素法がより有用であると思われた。

\section{Evaluation of creatinine determination by enzymatic assay and the Jaffe reaction method in peritoneal equilibration test}

\author{
Shinya Nakamura, Kaori Tomonaga, Midori Hojo, Kikuo litaka, Akira Nishida* \\ Department of Pediatrics, and Clinical Pathology*, Kitasato University School of Medicine
}

We measured creatinine in peritoneal dialysate by enzymatic assay (EA) and the Jaffe reaction method (J), to perform peritoneal equilibration tests (PET) in children. Average $\mathrm{D} 2 / \mathrm{P}$ ratios measured by $\mathrm{J}$ (corrected by glucose), and EA of D2/P were 0.494 and $0.478(p<0.01)$, respectively, and those of D4/P were 0.788 and $0.722(p<0.01)$, respectively. EA is more accurate and useful for measuring creatinine in peritoneal dialysate since this method is not influenced by the glucose concentration of the dialysate.

\section{緒言}

腹膜透析患者の腹膜機能の評価には Towardowski ら $)^{1)}$ 提唱した腹膜平衡機能検查 (PET) が行われている。その測定には透析液中のグル コースとクレアチニン $(\mathrm{Cr})$ 濃度の比を利用して おり， Cr の測定はヤッフェ直接法 (以下ヤッフェ 法と略す)と酵素法を用いて行っている。ヤッフエ 法は簡便な方法であるが，測定上いろいろな因子 に左右される欠点がある。特にグルコース濃度に 対する補正が必要とされている。今回我々は小児
の PET における透析液中の $\mathrm{Cr}$ の測定を酵素法 を用いて測定し，ヤッフェ法による測定值と比較 検討した。

\section{対象}

本院で CAPD 施行中の男子 14 例，女子 4 例の 計 18 例を対象とした。年歯は 5 歳 5 か月から 18 歳, 平均 12 歳 10 か月で, 透析期間は 2 か月から 78 か月, 平均 43 か月であった。原疾患は低形成腎 9 例，逆流腎症 2 例，慢性糸球体腎炎 3 例，多発 性動脈周囲炎 1 例，巣状糸球体硬化症 1 例，ネフ

中村 信也 北里大学小児科 于 228 相模原市北里 1-15-1 (0427-78-8111)

〔受付：平成 7 年 4 月 17 日，受理：平成 7 年 7 月 6 日〕 
ローゼ症候群 1 例, 先天性ネフローゼ症候群 1 例 であった。

\section{方法}

1.クレアチニンの測定

1) ヤッフェ法

HITACHI 7150 (日立製) を使用し，ヤッフェ 直接レート法試薬（デンカ生研製）を用い，測定 波長は $600 / 505 \mathrm{~nm}$ で吸光度を測定した ${ }^{2)}$.

2) 酵素法

TBA-30R (東芝製) を使用し, UV 法試薬 (デ ンカ生研製）を用い, 測定波長は $340 / 524 \mathrm{~nm}$ で $\mathrm{NADH}$ の増加による吸光度の変化を測定し $た^{3)}$.

3 ) 液体クロマトグラフィー (HPLC) 法

HPLC 装置, カラムは Shim-pak ISC05/S0504 (島津社製) を使用し, 流速 $0.7 \mathrm{ml} /$ 分, カラム温 度 $40^{\circ} \mathrm{C}$, 検出波長 $234 \mathrm{~nm}$, 検出器感度フルケース 0.64 前後の条件下で測定を行った。溶解液は 10 $\mathrm{mM}$ リン酸緩衝液（100 mM 硫酸ナトリウム含 む) pH 5.75 を使用した4)。

これらの測定にはデンカ生研製クレアチニン標 準液 $5.00 \mathrm{mg} / \mathrm{d} l$ を使用した。

2 . 検体の測定

1) 酵素法は他の物質の影響を受けにくい測定 法であるが, 確認の意味で, 今回 PET 施行時に 使用した透析液の Cr 值を HPLC 法と酵素法で 測定し比較した。

2) C Cr を含まない各種濃度のグルコース溶液 を作成し, 酵素法およびヤッフェ法で測定し,ヤッ フェ法による測定值のグルコースに対する補正式 を求めた。

3 ）透析液中の $\mathrm{Cr}$ 值 (DCr) の測定を酵素法 およびヤッフェ法で行い，両者の測定值を用いて 2 時間目の $\mathrm{D} 2 / \mathrm{P}(\mathrm{Cr})$ と 4 時間目の $\mathrm{D} 4 / \mathrm{P}(\mathrm{Cr})$ を求め, 相違を検討した（ $\mathrm{P}=$ 血清クレアチニン 值).

3 . 検定方法

二群間の相関は，回帰分析， $t$-test で求めた。

\section{結果}

1. 透析液中のグルコース濃度と $\mathrm{Cr}$ 濃度

PET で採取した 18 例の全透析液中のグルコー



図 1 HPLC 法と酵素法を用いて測定した透析 液中クレアチニン值の相関 (HPLC 法対酵 素法)

ス濃度は $217 \sim 2,234 \mathrm{mg} / \mathrm{d} l$ で,ヤッフェ法により 測定された透析液中 $\mathrm{Cr}$ 濃度（グルコース濃度補 正後）は $0.63 \sim 12.40 \mathrm{mg} / \mathrm{d} l$ であった.

2. HPLC 法と酵素法の $\mathrm{Cr}$ 測定の相関

今回の透析液検体の $\mathrm{Cr}$ 值を HPLC 法と酵素 法で測定したところ，両者の $\mathrm{Cr}$ 值の間には高度 の相関が得られ $(\mathrm{y}=0.968+0.17, \quad \mathrm{r}=0.997)$, 有意差を認めなかった $(\mathrm{p}=0.953)$ （図 1$)$.

3. $\mathrm{Cr}$ 測定に及湾すグルコース濃度の測定

各濃度のグルコース溶液を用いてヤッフェ法と 酵素法で $\mathrm{Cr}$ 值を測定した。酵素法による $\mathrm{Cr}$ 值 の測定はグルコース濃度による影響はみられな かったが, ヤッフェ法ではグルコース濃度に比例 して, $\mathrm{Cr}$ 值の上昇がタられ, 真の $\mathrm{Cr}$ 值 $(\mathrm{Cr}=0$ $\mathrm{mg} / \mathrm{d} l$ ) と差を認めた (図 2 )。この結果よりグル コース濃度に対する $\mathrm{Cr}$ の補正式として [真の $\mathrm{Cr}=\mathrm{Cr}$ (ヤッフェ法 $)-0.00031 \times$ 透析液中のグル コース濃度]が得られた。

4. 透析液中 $\mathrm{Cr}$ の測定：ヤッフェ法と酵素法 の比較

今回使用した腹膜透析液中の $\mathrm{Cr}$ 值の測定を ヤッフェ法と酵素法で行った。ヤッフェ法で測定 した Cr 值はグルコース濃度で補正した。両者の 測定値の間には相関係数で $\mathrm{r}=0.998$ と非常に良 好な相関が得られた $[y=1.020 x+0.031]$ (図 3 ). さらに両集団は $t$-test で $\mathrm{p}=0.001$ と有意差が得 


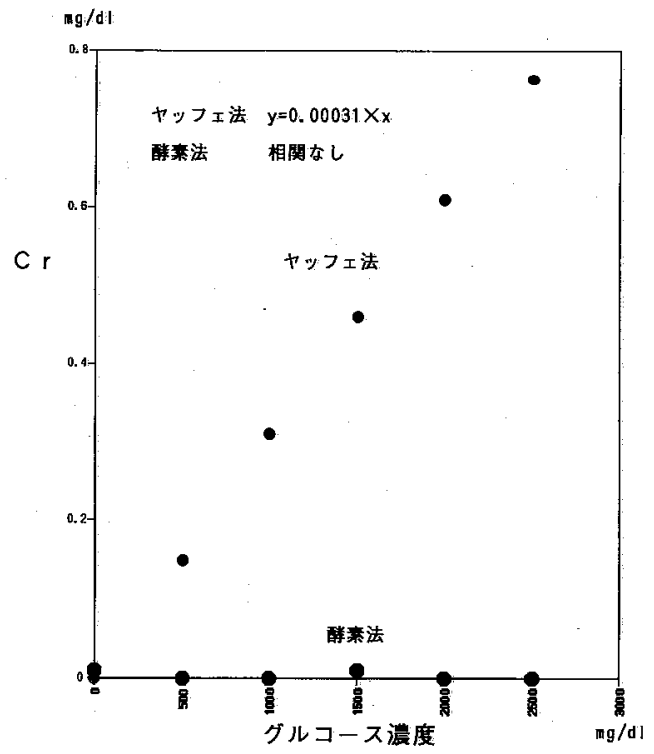

図 2 ヤッフェ法と酵素法での各種グルコース溶 液に招けるクレアチニシ測定值の変化

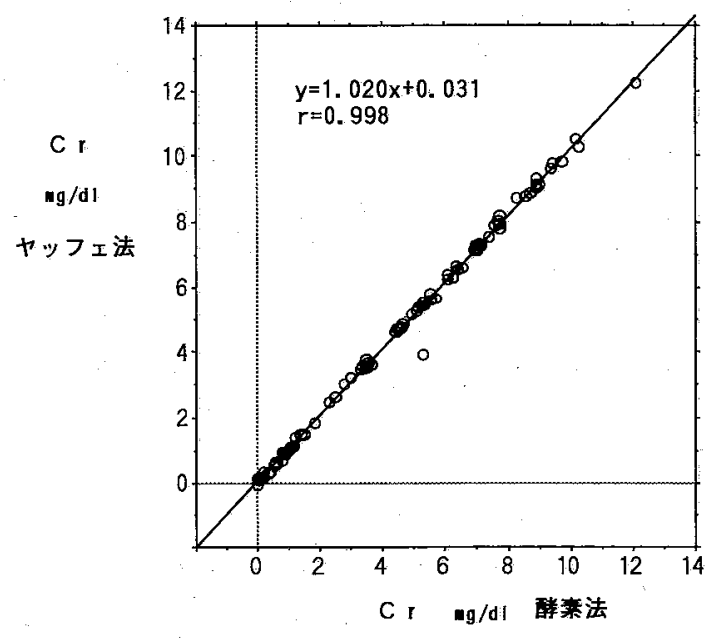

図 3 ヤッフェ法 (糖補正後) と酵素法により測 定した透析液中のクレアチニン值の相関



図 4 酵素法とヤッフェ法で測定したクレアチニン值を用いて得られた腹膜平 衡機能検查值の比較

られた。

5.ヤッフェ法で測定した Cr 值をグルコース 濃度で補正した後に得られた D2/P (Cr) と D4/ $\mathrm{P}(\mathrm{Cr})$ の平均は各々 0.494 と 0.788 で, 酵素法に よる $\mathrm{D} 2 / \mathrm{P}(\mathrm{Cr})$ と $\mathrm{D} 4 / \mathrm{P}(\mathrm{Cr})$ の平均は各々 0.478 と 0.722 となって扔り腹膜平衡機能の值に 差がみられた $(t$-test $\mathrm{p}<0.01$ ) (図 4 )。

\section{考察}

近年 $\mathrm{Cr}$ の測定は，除蛋白を行わないアルカリ 性ピクリン酸の呈色反応 (Kinetic Jaffe 法) ${ }^{3,4)}$ 利用した自動分析装置が多く用いられている。こ の反応系は測定值に影響を与元る物質が多く存在 することが知られておりり，その影響を除くため， 醭素法を用いた測定法の有效性が報告されてい 
る $^{6,7)}$.

腹膜平衡機能検查は 1987 年 Twardowski ら ${ }^{1)}$ が成人例における結果を報告し，現在透析患者の 腹膜機能の評価に役立っている．腹膜の除水能と 拡散能を透析液中のグルコース濃度の低下率と $\mathrm{Cr}$ 濃度の透析液/血清比の経時的変化を測定して 評価する。透析液中には高濃度のグルコースが存 在するため，ヤッフェ法を用いて Cr を測定する にはグルコースに対する補正式が必要である。

Twardowski らは補正式として [真の $\mathrm{Cr}=\mathrm{Cr}$ (ヤッフェ法) $-0.00033 \times$ 透析液中のグルコース 濃度］で計算することを推奖した。しかしいろい ろな測定機械が存在するため，各々の施設でのグ ルコースに対する独自の補正式が必要であると後 に訂正している。今回我々の検討の結果, 補正式 として [真の $\mathrm{Cr}=\mathrm{Cr}$ (ヤッフェ法 $)-0.00031 \times$ 透析液中のグルコース濃度] が得られた。酵素法 による $\mathrm{Cr}$ 測定に関しては透析液および透析排液 中に通常含まれる程度のグルコース,アルブミン， 尿酸, アンモニア，尿素窒素等ではほとんど影響 を受けないと報告されている。今回我々も $\mathrm{PET}$ で得られた 217〜2,234 mg/d $l$ のグルコース濃度 の透析液について, 酵素法と HPLC 法で測定した ところ両者間では非常に良い相関が得られ, 酵素 法が他の物質に影響されないことを証明した。同 一検体をヤッフェ法で測定しグルコース濃度で補 正した Cr 值と酵素法で測定して得られた值とを 比較したところ, 両者間で $\mathrm{y}=1.020 \mathrm{x}+0.031$ ( $\mathrm{y}$ : ヤッフェ法, $\mathrm{x}$ : 酵素法) の回帰式が得られた。 相関係数, $r=0.998$ と非常に良认相関が得られた が, $t$ 検定では $\mathrm{p}=0.001$ と有意差を認めた。以上 の結果よりヤッフェ法による透析液中の Cr の測 定は，さらにグルコース以外の因子をも除外する 必要があると思われた(図 3 )。グルコース以外の 因子に関しての検索は今回は行っていないが,こ のような影響因子を含んだ $\mathrm{Cr}$ の測定方法は透析 液の測定には不向きではないかと思われた。
Twardowski らの補正式のみでは $\mathrm{D} 2 / \mathrm{P}(\mathrm{Cr})$, $\mathrm{D} 4 / \mathrm{P}(\mathrm{Cr})$ で $5 \%$ 前後の測定值の違いが生じる ことがわかった。腹膜機能検查における $\mathrm{Cr}$ の測 定は,グルコースや他の因子による影響が少なく， これらの因子による影響の補正を必要としない酵 素法がより正確で有用であると思われた。

稿を終えるにあたり，御校閲を賜りました北里大 学小児科主任教授松浦信夫先生に深謝いたします。

なお, 本論文の要旨は第 36 回日本腎臓学会(横浜) において報告した。

\section{文献}

1) Twardowski $Z J:$ Peritoneal equilibration test. Perit Dial Bull 7 :138-147, 1987

2) Jaffe $M$ : Ueber den Niederschlang, welchen Pikrinsaoure in nomalen Harn erzeugt und uber eine neue Reaktion des Kreatinins. $Z$ Physiol Chem $10: 391-400,1886$

3) Larsen $K$ : Creatinine assay by a reactionkinetics principle. Clin Chem Acta $41: 209-$ 217, 1972

4) Taussky HH : A procedure increasing the specifieity of the Jaffe raction for the determination of creatine and creatinine in urine and plasma. Clin Chem Acta $1: 210-214,1956$

5) Miller B, Dubos R : Determination by a specific enzymatic method of the creatinine content of blood and urine from normal and nephrotic individual. J Biol Chem 121:457, 1937

6) Yasuhara M, Fujita S, Arisue K, Kohda K, Hayasi $\mathrm{C}$ : A new enzymatic method to determine creatinine. Clin Chem Acta 122:181188, 1982

7）中野幸弘, 松森康有：日立 736 形自動分析装置 におけるクレアチニン酵素法の比較検討。日本 臨床検査自動化学会会誌 $16: 72-77,1991$ 